\title{
Effect of Light Regulation on the Quality of Sweetpotato Sprouts
}

\author{
Zunfu Lv, Simeng Zhang, and Guoquan Lu \\ College of Agriculture and Food Science, Zhejiang A\&F University/Zhejiang \\ Key Laboratory of Agricultural Product Quality Improvement Technology, \\ Lin'an, Zhejiang 311300, China
}

Additional index words. illumination, nutritional quality, photoperiod, sweetpotato, yield

\begin{abstract}
Sweetpotato sprouts are buds or young shoots formed under dark or low-light conditions that can be eaten directly by people. This study was conducted to investigate the effects of light intensity and photoperiod on the quality and yield of sweetpotato sprouts and to identify the most suitable production conditions to provide a theoretical basis and technical parameters for the production of these vegetables. Four treatments involving different light intensities and photoperiods were set up: WL-1, WL-2, SL-1, and SL-2. The leaf color, nutritional quality, antioxidant capacity, texture characteristics, and yield of the sweetpotato sprouts were analyzed using Duncan's new complex range method. The results demonstrated the following: 1) an increase in photoperiod improved leaf brightness and enhanced the appearance of the product, whereas light intensity had little effect on these parameters; and 2) low light intensity increased the yield of sweetpotato sprouts, whereas high light intensity reduced their yield. Under weak light conditions, the quality and yield of sweetpotato sprouts were improved, and their taste was unaffected. Therefore, the condition of $750 \mu \mathrm{mol} \cdot \mathrm{m}^{-2} \cdot \mathrm{s}^{-1}$ for $2 \mathrm{hours} / \mathrm{day}$ was chosen to produce crispy, high-quality, and high-yielding sweetpotato sprouts.
\end{abstract}

China is the world's largest sweetpotato producer, with annual plantings and total production accounting for $70 \%$ and $85 \%$, respectively, of the world's supply (Tang et al., 2010). Sweetpotato sprouts are an ideal green vegetable with a high yield, high fiber and protein contents, and low oxalic acid content (Villareal et al., 1979). Ishida et al. (2000) reported that the total dietary fiber content of sweetpotato leaves is 5.90 to 7.00 $\mathrm{g} / 100 \mathrm{~g}$. The young leaves of stem tips are rich in protein, carotene, vitamin $\mathrm{C}$, and minerals such as calcium, phosphorus, and iron, with significantly higher contents than those of sweetpotato roots. Because of their multifunctional contents, sweetpotato sprouts are beneficial to the human body (Islam et al., 2002).

Given the high nutritive value of sweetpotato sprouts, the identification of better cultivation techniques to improve their quality is essential. Traditionally, sweetpotato sprouts are grown at temperatures of 25 to

\footnotetext{
Received for publication 10 Dec. 2020. Accepted for publication 11 Jan. 2021.

Published online 9 February 2021.

This work was supported by the Natural Science Foundation of China (grants 32071897, 31701322, 31671750), the earmarked fund for China agriculture research system (CARS-10-B-19), and a special agricultural project on new cultivar selection of drought crops in Zhejiang Province (2016C02050-7-5). Z.L. and S.Z. contributed equally to this work. G.L. is the corresponding author. E-mail: lugq10@ zju.edu.cn.

This is an open access article distributed under the CC BY-NC-ND license (https://creativecommons. org/licenses/by-nc-nd/4.0/).
}

$35{ }^{\circ} \mathrm{C}$ and $85 \%$ to $95 \%$ humidity. However, recent research findings could change the conception of the ideal cultivation environment for sprouts. Hong et al. (2008) reported that light has an important influence on the quality of mung bean sprouts. Pérez-Balibrea et al. (2008) found that light can increase the vitamin C, glucoside, and phenolic compound contents of broccoli and improve its nutritional value. $\mathrm{Lu}$ et al. (2014) found that light regulation can increase the antioxidant content of radish buds, and Thwe et al. (2014) discovered that blue light increases the phenolic compound content of tartary buckwheat malt. Eskins et al. (1995) demonstrated that light affected the shape and bitterness of lettuce, whereas Fan et al. (2004) found that radiation has no effect on the quality of axillary buds. Li (2015) found that the taste of sweetpotato sprouts worsened but the nutritional value improved with increased photoperiod.

Sweetpotato sprouts are vegetables that can be grown by the consumer. They are easy to grow and have a high nutritional value and pleasing taste. Few reports describe cultivation techniques for sweetpotato sprouts, and in-depth research in this area could improve the production and value of this popular crop. This study was conducted to identify a better cultivation technique and provide the theoretical basis and details of the technical methods required for the optimized production of sweetpotato sprouts.

\section{Materials and Methods}

Test materials. The sweetpotato cultivars used were Fushu 7-6, Xushu 22, and Shangshu 19. Seedlings were planted in the intelligent greenhouse of the Zhejiang
Agriculture and Forestry University. A single row of high ridges was adopted (ridge height $30 \mathrm{~cm}$, ridge width $50 \mathrm{~cm}$, groove width 30 $\mathrm{cm}$, plant spacing $30 \mathrm{~cm}$ ). In total, $80 \mathrm{spec}-$ imens of each variety were planted and harvested after $110 \mathrm{~d}$ of growth.

Experimental design. Sweetpotato sprouts were cultivated in a smart incubator with a built-in LED white light source. Dark conditions were used as a control. The specific treatments are shown in Table 1. Sweetpotato roots $(150+50 \mathrm{~g})$ without pests or diseases were selected and placed in a germination box $(18 \times 12 \times 8 \mathrm{~cm})$. Five sweetpotato roots were placed in each box, with three replications. In the early stage, the sweetpotato roots were disinfected for $15 \mathrm{~min}$ with $50 \%$ carbendazim diluted 500 times, after which they were placed in the incubator (all dark, relative humidity $85 \%$ ) at $35{ }^{\circ} \mathrm{C}$. After $3 \mathrm{~d}$ of sprouting, the temperature was adjusted to $32{ }^{\circ} \mathrm{C}$. The sweetpotato roots were then treated with different light intensities and photoperiods, and the temperature was regulated to $30{ }^{\circ} \mathrm{C}$. Four treatments involving different light intensities and photoperiods were set up: WL-1 $\left(750 \mu \mathrm{mol} \cdot \mathrm{m}^{-2} \cdot \mathrm{s}^{-1}, 1 \mathrm{~h} / \mathrm{d}\right)$, WL-2 $\left(750 \mu \mathrm{mol} \cdot \mathrm{m}^{-2} \cdot \mathrm{s}^{-1}, 2 \mathrm{~h} / \mathrm{d}\right), \mathrm{SL}-1$ (2250 $\left.\mu \mathrm{mol} \cdot \mathrm{m}^{-2} \cdot \mathrm{s}^{-1}, \quad 1 \mathrm{~h} / \mathrm{d}\right)$, and SL-2 (2250 $\left.\mu \mathrm{mol} \cdot \mathrm{m}^{-2} \cdot \mathrm{s}^{-1}, 2 \mathrm{~h} / \mathrm{d}\right)$. The sweetpotato sprouts were harvested when they grew to about 14 $\mathrm{cm}$.

Determination of texture parameters of sweetpotato sprouts. The methods for measuring texture parameters followed the protocols described by Alessandrini et al. (2010). Hardness is the maximum strength peak for the first extrusion cycle; it reflects the resistance of the sample to deformation, and its unit is N. Cohesion is the ratio of the positive peak area of the second extrusion cycle to the positive peak area of the first extrusion cycle, and it reflects the resistance to breakage and tight connections during sweetpotato sprout chewing, keeping sweetpotato sprout intact. Elasticity is the degree to which the sample can recover after the first compression before the second compression, and it is expressed by the ratio of the height of the second compression to that of the first compression in millimeters. Adhesion is the force required to break the sweetpotato sprouts before it is swallowed, and it is in units of $\mathrm{N}$. Adhesion $=$ Hardness $\times$ Cohesiveness. Chewiness is used to describe the characteristics of solid test samples, defined as the force required by teeth to chew sweetpotato sprouts into swallowing state. In addition, Chewiness comprehensively reflects its continuous resistance to chewing, and its unit is N. Chewiness $=$ Hardness $\times$ Elasticity $\times$ Cohesiveness.

Determination of various characteristics. The leaf color parameters were determined by a portable color difference meter (HP2132), and the water content was measured using a drying method at $105{ }^{\circ} \mathrm{C}$. The soluble sugar content was determined by anthrone colorimetry ( $\mathrm{Li}, 2000)$, and the vitamin $\mathrm{C}$ content was determined by ultraviolet colorimetry (Arya et al., 2000). Texture 
Table 1. Cultivation conditions.

\begin{tabular}{|c|c|c|c|}
\hline Variety & Light intensity $\left(\mu \mathrm{mol} \cdot \mathrm{m}^{-2} \cdot \mathrm{s}^{-1}\right)$ & Lighting cycle (h/d) & Remarks \\
\hline & Darkness & 0 & Dark (control) \\
\hline Xushu 22 & 750 & 1 & Weak light (WL-1) \\
\hline Shang 19 & 750 & 2 & Weak light (WL-2) \\
\hline Fushu 7-6 & 2250 & 1 & Strong light (SL-1) \\
\hline & 2250 & 2 & Strong light (SL-2) \\
\hline
\end{tabular}

characteristics were measured using a texture analyzer produced by the Food Technology Corporation Company of America (Sterling, VA). The probe, with a diameter of $0.5 \mathrm{~cm}$, was located $15 \mathrm{~mm}$ from the sample. The initial force was $0.15 \mathrm{~N}$, and the deformation percentage was 90 . The testing speed was 30 $\mathrm{mm} / \mathrm{min}$, and the testing position was in the center of the sweetpotato sprout ( $\mathrm{Lv}$ et al., 2018). The crude protein content was determined by the Kjeldahl method. The anthocyanin concentration was determined using the $\mathrm{pH}$ differential method (Lee et al., 2005). The chlorophyll content was measured via acetone-ethanol extraction. The 2,2diphenyl-1-picrylhydrazyl (DPPH) clearance rate was determined using the Hsu method (Hsu et al., 2003).

Data Processing. Statistical analyses were performed using Excel 2007 (Microsoft Corp., Redmond, WA) and SPSS (version 19.0; IBM Corp., Armonk, NY) software. Duncan's new multiple range method was used for multiple comparisons.

\section{Results}

Effects of light regulation on leaf color of sweetpotato sprouts. The leaf color of 'Fushu 7-6' and 'Xushu 22' changed significantly under different light treatments (Fig. 1, Table 2 ). The light intensity had no obvious effect on leaf color, but the prolonged photoperiod had a significant effect. In terms of green leaf color, the color intensity was ranked as follows: WL-1 < WL-2 and SL-1 < SL-2. The leaf color of 'Shangshu 19' did not differ significantly under different light treatments but began to change from red to yellow-green under the SL-2 treatment (Fig. 1).

Effects of light regulation on the nutritional quality of sweetpotato sprouts. The water content of sweetpotato sprouts grown under dark conditions was higher than that of sprouts grown under light conditions. The water content of 'Xushu 22' and 'Shangshu 19' sweetpotato sprouts grown in light and dark conditions did not differ significantly (Fig. 2). However, the water content of 'Fushu 7-6' sweetpotato sprouts varied significantly depending on whether they were grown in light or dark cultivation conditions.

The soluble sugar contents of 'Fushu 7-6' and 'Xushu 22' were higher in sprouts grown in dark conditions (Fig. 3). The soluble sugar content of 'Fushu 7-6' differed significantly between the WL-1 and dark conditions. There was no significant difference in soluble sugar content between the light and dark treatment. In general, the light intensity and photon-cycle had little effect on the soluble sugar content of 'Xuzhou 22' sweetpotato
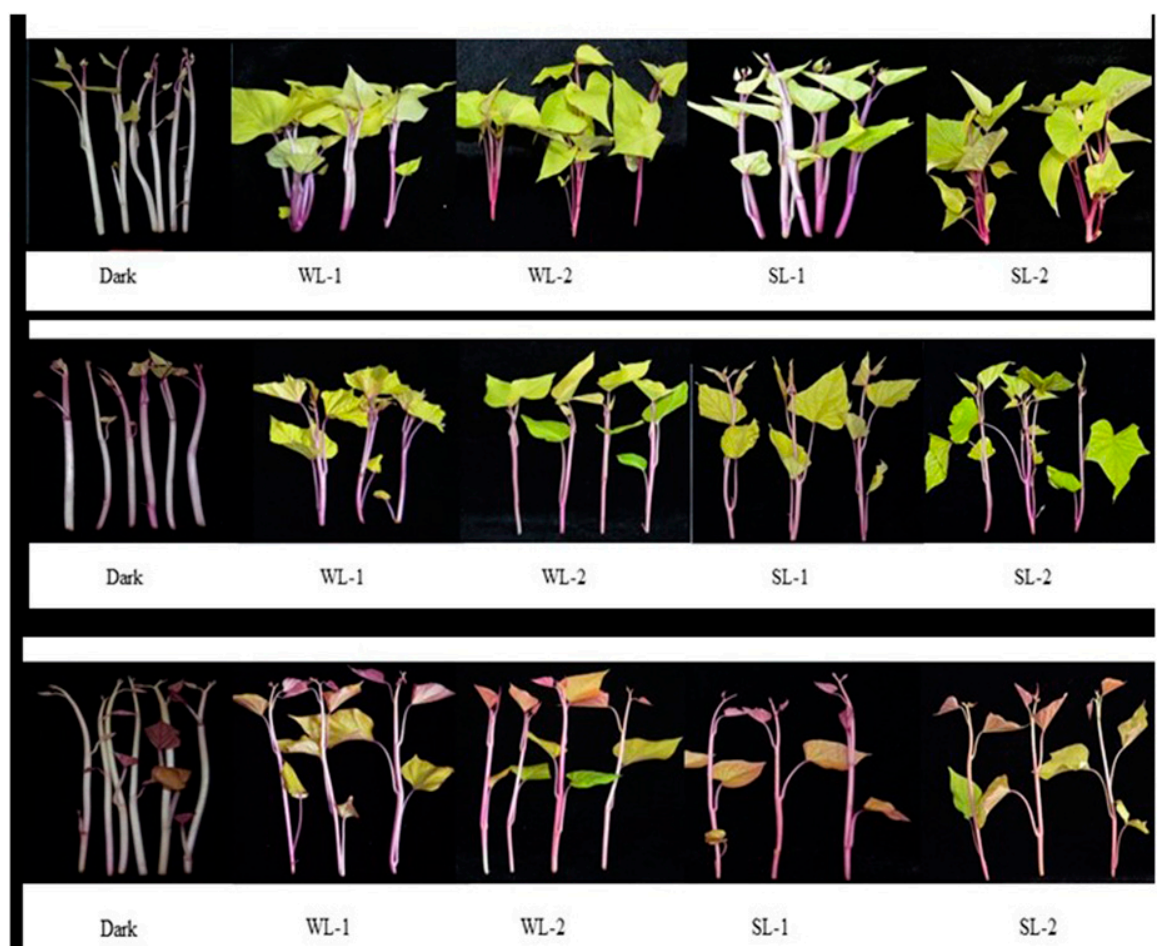

Fig. 1. The changes in leaf color of 'Fushu 7-6', 'Xushu 22', and 'Shangshu 19' sweetpotato sprouts under different light treatments.

buds, and the quality of 'Fushu 7-6' and 'Xushu 22' bud vegetables was lower than that of other treatments under SL-2 light. There was a significant difference in soluble sugar content between 'Fushu 7-6' and 'Xushu 22' under the light condition of SL1 and SL-2, whereas there was a significant difference in soluble sugar content between 'Shangshu 19' buds under the light condition of SL-1 and SL-2. Therefore, we can determine that the higher photoperiod and light intensity reduce the soluble sugar content of sweetpotato buds. The vitamin $\mathrm{C}$ content of sweetpotato sprouts grown under light conditions was higher than that obtained under dark conditions. The vitamin $\mathrm{C}$ content of 'Fushu 7-6' grown in light and dark cultivation conditions did not differ significantly (Fig. 4). However, the vitamin C content of 'Xushu 22' was significantly higher when it was grown under light conditions than when it was grown under dark conditions. Additionally, the vitamin $\mathrm{C}$ content of this cultivar was higher when measured after a longer photoperiod than when measured after a short photoperiod. 'Xushu 22' sprouts grown under the WL-2 and SL-2 treatment conditions contained significantly different amounts of vitamin $\mathrm{C}$ than did those that received the WL-1 treatment.

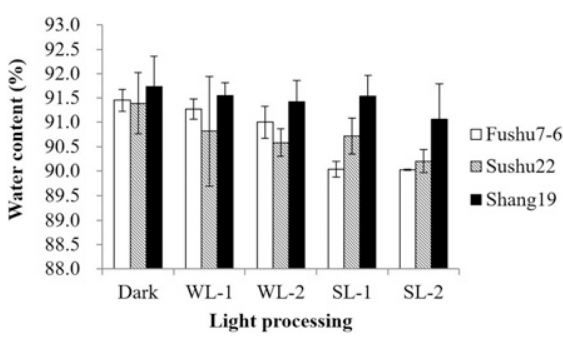

Fig. 2. Effect of different light treatments on water content of sweetpotato sprouts.

The crude protein content differed significantly between sweetpotato sprouts grown under dark and light treatment conditions. 'Fushu 7-6' sprouts contained significantly different amounts of crude protein when grown under different light intensities and photoperiods. Their protein content was highest when grown under weak light for a shorter photoperiod (WL-1; Fig. 5).

Effect of light regulation on antioxidant activity of sweetpotato sprouts. Under dark conditions, the anthocyanin content and DPPH clearance rate of 'Xushu 22', 'Shangshu 19', and 'Fushu 7-6' sweetpotato sprouts were lowest (Table 3) and differed significantly 
from those of sprouts grown under light conditions. The anthocyanin contents of 'Shangshu 19' and 'Fushu 7-6' were higher when measured after a longer photoperiod treatment than when measured after a short photoperiod. Under weak light conditions, the DPPH clearance rate of 'Shangshu 19' sweetpotato sprouts was highest; the DPPH clearance rate

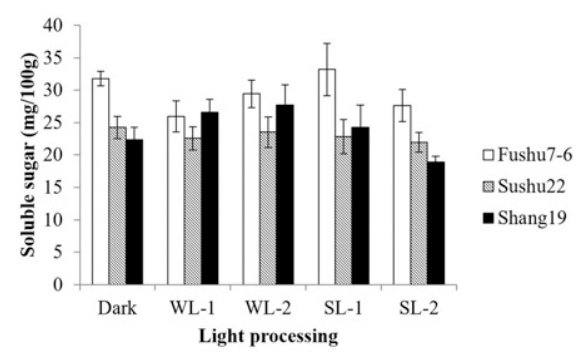

Fig. 3. Effect of different light treatments on soluble sugar of sweetpotato sprouts.

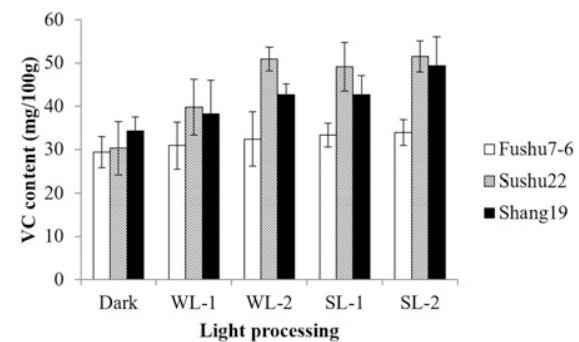

Fig. 4. Effect of different light treatments on vitamin $\mathrm{C}$ contents of sweetpotato sprouts. of 'Fushu 7-6' sweetpotato sprouts differed significantly under different photoperiods.

Effects of light regulation on the texture characteristics of sweetpotato sprouts. The chewiness of the sweetpotato sprouts was lowest when the sprouts were grown under dark treatment conditions and increased significantly with the light intensity and photoperiod (Table 4). Compared with the other treatments, the hardness, elasticity, and chewiness of the sprouts grown with the SL-2 treatment were greatest, and these differences were significant $(P<0.05)$. Compared with strong light treatment, low light treatment yielded sweetpotato sprouts with lower hardness values.

Correlations between leaf color and texture characteristics of sweetpotato sprouts. The $\mathrm{L}^{*}$ value showed an extremely significant negative correlation with the a* value $(r=-0.456, P<$ 0.01 ), an extremely significant positive correlation with the $\mathrm{b}^{*}$ value $(r=0.752, P<0.01)$, and an extremely significant negative correlation

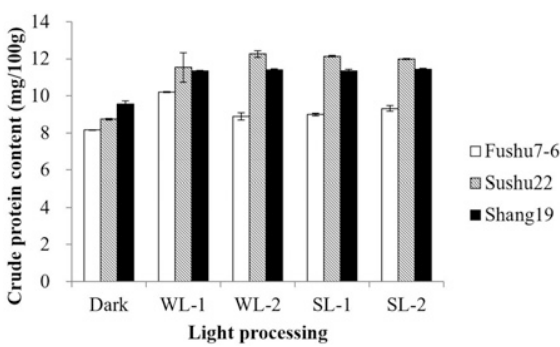

Fig. 5. Effect of different light treatments on crude protein contents of sweetpotato sprouts. with hardness $(r=-0.415, P<0.01$; Table 5$)$. The $\mathrm{b}^{*}$ value correlated negatively with the $\mathrm{a}^{*}$ value $(r=-0.759, P<0.01)$, cohesion correlated positively with elasticity $(r=0.580, P<$ $0.01)$, and adhesion correlated positively with hardness $(r=0.792, P<0.01)$ and cohesion $(r=$ $0.592, P<0.01)$. These results suggest that as the color of the sweetpotato sprouts deepened, the appearance became more appealing, but the taste became less enjoyable.

Correlations between leaf color and nutritional quality of sweetpotato sprouts. The L* value of the sweetpotato spouts correlated positively with the soluble sugar content $(r=0.389, P<0.01$; Table 6$)$ and negatively with the vitamin $\mathrm{C}(r=-0.406, P<0.01)$, crude protein $(r=-0.422, P<0.01)$, and anthocyanin $(r=-0.424, P<0.01)$ contents, as well as the DPPH clearance rate $(r=-0.614, P<0.01)$. The $\mathrm{a}^{*}$ value correlated positively with the water content $(r=0.622, P<0.01)$ and the $\mathrm{b}^{*}$ value correlated negatively with the water content $(r=-0.536, P<0.01)$. These results show that a darker leaf color correlated with a higher DPPH clearance rate and increased vitamin C, crude protein, and anthocyanin contents.

Correlations between texture characteristics and nutritional quality of sweetpotato sprouts. The hardness of sweetpotato spouts correlated negatively with the soluble sugar content $(r=-0.389, P<0.01)$ and positively with the vitamin $\mathrm{C}(r=0.477, P<0.01)$, crude protein $(r=0.403, P<0.01)$, and anthocyanin $(r=0.361, P<0.05)$ contents and DPPH clearance rate $(r=0.478, P<0.01$; Table 7$)$. The chewiness of the potato sprouts correlated positively with the anthocyanin content

Table 2. The multiple comparisons of leaf color parameters of sweetpotato sprouts under different light treatments.

\begin{tabular}{|c|c|c|c|c|}
\hline Variety & Processing & $\mathrm{L}^{*}$ value & a* value & $\mathrm{b}^{*}$ value \\
\hline \multirow[b]{2}{*}{ Fushu 7-6 } & Dark & $69.90 \pm 1.31 \mathrm{~b}$ & $1.57 \pm 0.52 \mathrm{a}$ & $39.24 \pm 2.70 \mathrm{~b}$ \\
\hline & WL-2 & $69.10 \pm 1.95 \mathrm{~b}$ & $-5.78 \pm 1.12 \mathrm{c}$ & $45.22 \pm 0.63 \mathrm{a}$ \\
\hline \multirow[b]{3}{*}{ Xushu 22} & Dark & $71.74 \pm 1.67 \mathrm{a}$ & $1.30 \pm 0.58 \mathrm{a}$ & $39.63 \pm 3.19 \mathrm{c}$ \\
\hline & WL-1 & $69.20 \pm 0.57 \mathrm{~b}$ & $-1.09 \pm 1.62 b$ & $48.18 \pm 1.27 b$ \\
\hline & WL-2 & $63.13 \pm 0.65 \mathrm{c}$ & $-8.5 \pm 0.38 \mathrm{c}$ & $45.35 \pm 1.91 \mathrm{~b}$ \\
\hline \multirow{5}{*}{ Shangshu 19} & Dark & $54.97 \pm 2.67 \mathrm{a}$ & $12.03 \pm 3.08 \mathrm{a}$ & $25.01 \pm 3.42 \mathrm{c}$ \\
\hline & WL-1 & $56.46 \pm 1.40 \mathrm{a}$ & $12.93 \pm 1.93 \mathrm{a}$ & $27.81 \pm 2.20 b c$ \\
\hline & WL-2 & $55.46 \pm 0.20 \mathrm{a}$ & $9.53 \pm 2.32 \mathrm{a}$ & $36.20 \pm 1.10 \mathrm{a}$ \\
\hline & SL-1 & $58.13 \pm 1.53 \mathrm{a}$ & $10.93 \pm 0.78 \mathrm{a}$ & $30.64 \pm 1.90 \mathrm{~b}$ \\
\hline & SL-2 & $55.49 \pm 0.20 \mathrm{a}$ & $-4.4 \pm 1.20 b$ & $36.20 \pm 1.07 \mathrm{a}$ \\
\hline
\end{tabular}

$\mathrm{L}^{*}$ value $=$ the chromaticity value of the object color. $\mathrm{L}$ value $=$ the lightness: the smaller the value, the darker it is. $\mathrm{a}^{*}$ value $=$ red and green; a positive value indicates red, and a negative value indicates green. $\mathrm{b}^{*}=$ yellow and blue; a positive value indicates that the object is yellow, and a negative value is blue. $\mathrm{WL}=$ weak light; $\mathrm{SL}=$ strong light.

Lowercase letters indicate $P<0.05$ levels.

Table 3. The effects of anthocyanin and antioxidant on sweetpotato sprouts under different light treatments.

\begin{tabular}{|c|c|c|c|c|c|c|}
\hline \multirow[b]{2}{*}{ Processing } & \multicolumn{3}{|c|}{ Anthocyanin content $(\mathrm{mg} / 100 \mathrm{~g})$} & \multicolumn{3}{|c|}{ DPPH clearance rate $(\%)$} \\
\hline & $\mathrm{X}$ & $\mathrm{S}$ & $\mathrm{F}$ & $\mathrm{X}$ & $\mathrm{S}$ & $\mathrm{F}$ \\
\hline WL-1 & $1.46 \pm 0.44 \mathrm{~b}$ & $3.22 \pm 0.32 b$ & $2.06 \pm 0.05 \mathrm{c}$ & $90.62 \pm 0.64 b$ & $95.11 \pm 1.11 \mathrm{a}$ & $86.05 \pm 1.13 \mathrm{c}$ \\
\hline SL-2 & $2.57 \pm 0.23 \mathrm{a}$ & $3.37 \pm 0.14 \mathrm{~b}$ & $2.97 \pm 0.31 \mathrm{a}$ & $93.44 \pm 0.65 \mathrm{a}$ & $93.73 \pm 2.44 \mathrm{ab}$ & $91.73 \pm 2.39 \mathrm{a}$ \\
\hline
\end{tabular}

$\mathrm{WL}=$ weak light; $\mathrm{SL}=$ strong light; $\mathrm{X}=$ Xushu 22; $\mathrm{S}=$ Shang $19 ; \mathrm{F}=$ Fushu 7-6.

Lowercase letters indicate $P<0.05$ levels. 
Table 4. Effect of different light treatments on the texture characteristics of sweetpotato sprouts.

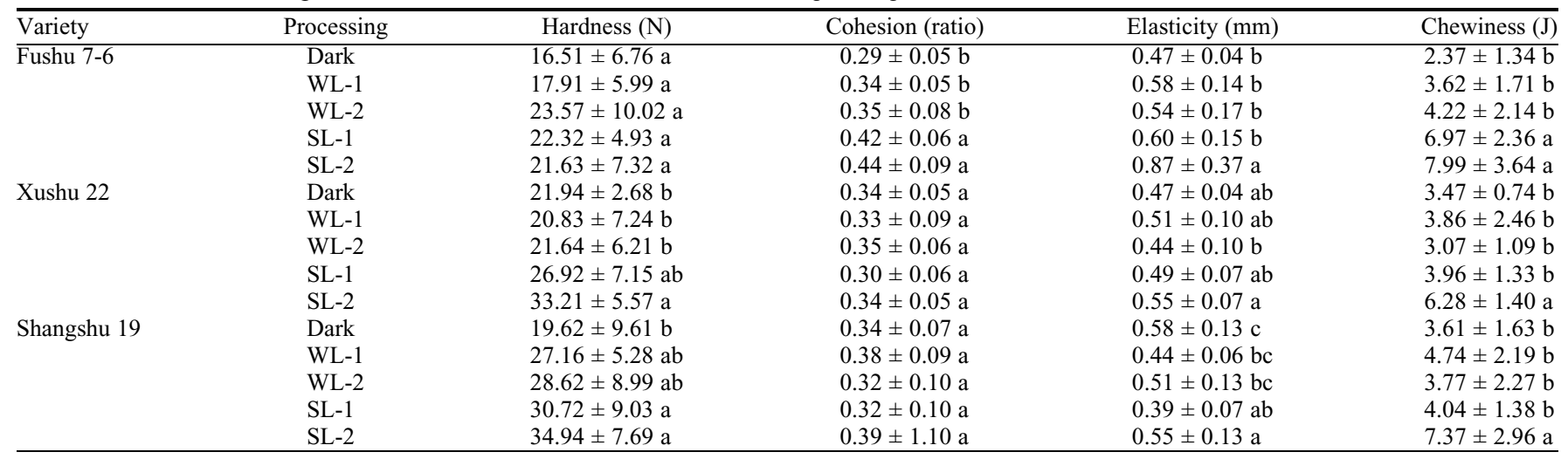

Chewiness $=$ hardness $\times$ cohesion $\times$ elasticity.

$\mathrm{WL}=$ weak light; $\mathrm{SL}=$ strong light.

Table 5. The correlation analysis of leaf color and texture characteristics of sweetpotato sprouts.

\begin{tabular}{|c|c|c|c|c|c|c|}
\hline Parameter & $\mathrm{L}^{*}$ value & $a^{*}$ value & Hardness & Cohesive & Elasticity & Adhesion \\
\hline$\overline{\mathrm{L}^{*} \text { value }}$ & 1 & & & & & \\
\hline$b^{*}$ value & $0.752 * *$ & $-0.759 * *$ & & & & \\
\hline Hardness & $-0.415^{* *}$ & -0.066 & 1 & & & \\
\hline Elasticity & 0.158 & -0.251 & 0.014 & $0.580 * *$ & 1 & \\
\hline Adhesion & -0.283 & -0.143 & $0.792 * *$ & $0.592 * *$ & 0.272 & 1 \\
\hline Chewiness & -0.096 & -0.263 & $0.482 * *$ & $0.691 * *$ & $0.764 * *$ & $0.763 * *$ \\
\hline
\end{tabular}

$\mathrm{L}^{*}$ value $=$ the chromaticity value of the object color. $\mathrm{a}^{*}$ value $=$ red and green; a positive value indicates red, and a negative value indicates green. $\mathrm{b}^{*}=$ yellow and blue; a positive value indicates that the object is yellow, and a negative value is blue.

** Significant correlation at the 0.01 level (both sides), $\mathrm{n}=45$.

Table 6. The correlation analysis of leaf color and nutritional quality of sweetpotato sprouts.

\begin{tabular}{|c|c|c|c|c|c|c|c|c|}
\hline & $\mathrm{L}^{*}$ value & $\mathrm{a}^{*}$ value & $\mathrm{b}^{*}$ value & Water content & Soluble sugar & Vitamin C & Crude protein & Anthocyanin \\
\hline Water content & -0.212 & $0.622^{* *}$ & $-0.536^{* *}$ & 1 & & & & \\
\hline Vitamin $\mathrm{C}$ & $-0.406^{* *}$ & -0.243 & 0.096 & $-0.362^{*}$ & $-0.556^{* *}$ & 1 & & \\
\hline Crude protein & $-0.422 * *$ & -0.052 & 0.086 & -0.270 & $-0.570 * *$ & $0.814^{* *}$ & 1 & \\
\hline DPPH clearance rate & $-0.614 * *$ & 0.170 & -0.215 & -0.131 & $-0.316^{*}$ & $0.573^{* *}$ & $0.666^{* *}$ & $0.653^{* *}$ \\
\hline
\end{tabular}

$\mathrm{L}^{*}$ value $=$ the chromaticity value of the object color. $\mathrm{a}^{*}$ value $=$ red and green; a positive value indicates red, and a negative value indicates green. $\mathrm{b}^{*}=$ yellow and blue; a positive value indicates that the object is yellow, and a negative value is blue.

*, ${ }^{* *}$ Significant correlations at the 0.05 and 0.01 levels (both sides), respectively, $\mathrm{n}=45$.

Table 7. The correlation analysis of textural characteristics and nutritional quality of sweetpotato sprouts.

\begin{tabular}{lccc}
\hline & Hardness & Adhesion & Chewiness \\
\hline Water content & -0.076 & -0.066 & -0.145 \\
Soluble sugar & $-0.389^{* *}$ & $-0.300^{*}$ & -0.003 \\
Vitamin C & $0.477^{* *}$ & 0.274 & 0.060 \\
Crude protein & $0.403^{* *}$ & 0.173 & 0.078 \\
Anthocyanin & $0.361^{*}$ & 0.240 & $0.399^{* *}$ \\
DPPH clearance & $0.478^{* *}$ & $0.345^{*}$ & $0.381^{* *}$
\end{tabular}
rate

$*, * *$ Significant correlations at the 0.05 and 0.01 levels (both sides), respectively, $\mathrm{n}=45$.

$(r=0.399, P<0.01)$ and DPPH clearance rate $(r=0.381, P<0.01)$. These results suggest that as the hardness of the sweetpotato sprouts increased, the soluble sugar content decreased, the DPPH clearance rate increased, and the vitamin $\mathrm{C}$, crude protein, and anthocyanin contents increased, indicating that the taste of sweetpotato sprouts became less appealing as the nutritional quality improved.

Effects of different light treatments on the yield of sweetpotato sprouts. The total yields of the three varieties of sweetpotato sprouts were highest under the WL-2 treatment (750 $\left.\mu \mathrm{mol} \cdot \mathrm{m}^{-2} \cdot \mathrm{s}^{-1}, 2 \mathrm{~h} / \mathrm{d}\right)$ and lowest under the SL-2 treatment $\left(2250 \mu \mathrm{mol} \cdot \mathrm{m}^{-2} \cdot \mathrm{s}^{-1}, 2 \mathrm{~h} / \mathrm{d}\right)$. Under dark conditions, the numbers of sweetpotato sprouts were largest. The total numbers of 'Fushu 7-6', 'Xushu 22', and 'Shangshu 19' plants were 250,290 , and 308 , respectively (Table 8). The single plant weights of sweetpotato sprouts grown under the WL-1 and WL-2 treatments were greater than those of sprouts grown under the other treatments. The single plant weights of 'Fushu 7-6' and 'Shangshu 19' were lowest under SL-1 conditions, whereas the single plant weights of 'Fushu 7-6' and 'Xushu 22' were lowest under WL-1 conditions.

\section{Discussion}

Effects of light regulation on leaf color of sweetpotato sprouts. Mølmann et al. (2015) found that the color and size of cauliflower were affected by different treatments of pho- toperiods. In our study, light intensity had little effect on the leaf color of sweetpotato sprouts, whereas the photoperiod had a large impact on leaf color. Analysis of correlations between leaf color and texture parameters showed that the $\mathrm{L}^{*}$ value correlated negatively with the a* value and hardness, indicating that the color of the sprouts became yellow as $\mathrm{L}^{*}$ value increased. The hardness of yellow sweetpotato sprouts was lower than that of green sweetpotato sprouts.

Effects of light regulation on the nutritional quality of sweetpotato sprouts. Shi et al. (2007) found that increased light can increase the accumulation of soluble sugar, starch, and anthocyanins in plants. Other researchers ( $\mathrm{Li}$ and Kubota, 2009; Son and Oh, 2013) influenced the anthocyanin, carotenoid, and phenolic compound contents of lettuce by adjusting the light quality. In our study, the water and vitamin $C$ contents of sweetpotato sprouts grown under light conditions were higher than those of sprouts grown under dark conditions. Light 
Table 8. Effect of different light treatments on yield of sweetpotato sprouts.

\begin{tabular}{|c|c|c|c|c|c|c|}
\hline$\overline{\text { Variety }}$ & Treatment & Plant wt (g) & No. of plants & Stubble yield $(\mathrm{g} / \mathrm{kg})$ & Total no. of plants & Total yield $(\mathrm{g} / \mathrm{kg})$ \\
\hline \multirow[t]{3}{*}{ Fushu 7-6 } & Dark & $1.02 \pm 0.09 \mathrm{bc}$ & $50.00 \pm 4.15 \mathrm{ab}$ & $51.02 \pm 5.38 \mathrm{ab}$ & 250.00 & 255.10 \\
\hline & WL-2 & $1.29 \pm 0.12 \mathrm{a}$ & $42.04 \pm 7.87 \mathrm{bc}$ & $54.46 \pm 5.98 \mathrm{a}$ & 212.00 & 272.32 \\
\hline & SL-1 & $0.83 \pm 0.01 \mathrm{c}$ & $45.06 \pm 2.72 b c$ & $35.22 \pm 2.98 \mathrm{bc}$ & 228.00 & 190.10 \\
\hline \multirow[t]{3}{*}{ Xushu 22} & Dark & $0.81 \pm 0.05 \mathrm{c}$ & $58.00 \pm 7.79 \mathrm{a}$ & $46.76 \pm 10.97 \mathrm{~b}$ & 290.00 & 233.78 \\
\hline & WL-1 & $1.51 \pm 0.12 \mathrm{a}$ & $34.00 \pm 2.20 \mathrm{c}$ & $51.20 \pm 3.30 \mathrm{~b}$ & 170.00 & 255.96 \\
\hline & WL-2 & $1.46 \pm 0.27 \mathrm{a}$ & $42.00 \pm 7.22 \mathrm{ab}$ & $60.98 \pm 13.4 \mathrm{a}$ & 208.00 & 304.92 \\
\hline \multirow{5}{*}{ Shangshu 19} & Dark & $0.87 \pm 0.07 \mathrm{c}$ & $62.00 \pm 7.49 \mathrm{a}$ & $54.06 \pm 10.17 \mathrm{ab}$ & 308.00 & 270.32 \\
\hline & WL-1 & $1.17 \pm 0.14 \mathrm{a}$ & $50.00 \pm 5.03 \mathrm{ab}$ & $56.08 \pm 3.26 \mathrm{ab}$ & 254.00 & 297.06 \\
\hline & WL-2 & $1.04 \pm 0.05 \mathrm{ab}$ & $60.00 \pm 3.38 \mathrm{ab}$ & $62.82 \pm 5.03 \mathrm{a}$ & 302.00 & 314.14 \\
\hline & SL-1 & $0.79 \pm 0.07 \mathrm{c}$ & $60.00 \pm 4.94 \mathrm{ab}$ & $46.42 \pm 5.78 \mathrm{ab}$ & 294.00 & 232.14 \\
\hline & SL-2 & $0.99 \pm 0.05 b$ & $44.00 \pm 7.15 b$ & $43.94 \pm 5.55 b$ & 222.00 & 219.68 \\
\hline
\end{tabular}

$\mathrm{WL}=$ weak light; $\mathrm{SL}=$ strong light.

regulation had a significant effect on the water content of 'Fushu 7-6'. It also had a significant effect on the vitamin $\mathrm{C}$ contents of 'Xushu 22' and 'Shangshu 19', and correlated positively with the photoperiod. Light regulation had a significant effect on the crude protein content of all three sweetpotato sprout varieties, but the difference according to light intensity was not significant. The accumulation of nutrients in the sweetpotato sprouts was greater under light conditions than under dark conditions. However, the hardness of sweetpotato sprouts correlated negatively with the soluble sugar content and positively with the vitamin C content, crude protein content, and DPPH clearance rate. These findings indicate that a higher nutritional value and antioxidant capacity of sweetpotato sprouts increases hardness and decreases chewiness. In addition, the vegetable feels crisper and more tender in the mouth when grown with a short photoperiod and low light intensity. Therefore, an appropriate light intensity and photoperiod could increase the nutrient content of the sweetpotato sprouts while decreasing hardness and improving chewiness.

Effect of light regulation on antioxidant activity in sweetpotato sprouts. Light regulation had a positive effect on the anthocyanin content of sweetpotato sprouts in our study. The photoperiod had a positive effect on anthocyanin content, and light regulation had a positive effect on the DPPH clearance rate. With increasing anthocyanin content, the DPPH clearance rate also rose. According to the correlation analysis, a lower light intensity and shorter illumination time will result in lower oxidation resistance in the sweetpotato sprouts. Therefore, an appropriate light intensity and photoperiod could improve the antioxidant capacity of sweetpotato sprouts. Świeca et al. (2012) found that photoperiod lengthening improved the antioxidant capacity of bean sprouts. This finding is similar to the results of this study. The DPPH clearance rate of sweetpotato sprouts correlated positively with the vitamin $\mathrm{C}$, crude protein, and anthocyanin contents. These results indicate that sweetpotato sprouts with deeper leaf color have greater nutritional quality and oxidation resistance.
Effect of light regulation on the yield of sweetpotato sprouts. Light regulation had a positive effect on the total yield of sweetpotato sprouts and a negative effect on the number of sweetpotato sprouts. Compared with weak light conditions, strong light inhibited the increase in single plant weight. Compared with a short photoperiod, a long photoperiod promoted an increase in single plant weight. Under a combination of strong light and a long photoperiod, the total yield of sweetpotato sprouts was lowest, due mainly to the small number of plants.

\section{Conclusion}

Compared with those obtained under dark conditions, the yield and quality of sweetpotato sprouts could be improved by increasing the time and intensity of illumination. However, excessive illumination time and intensity not only reduces the yield of sweetpotato sprouts, but also negatively affects their taste. Therefore, appropriate illumination is critical for the optimal cultivation of sweetpotato sprouts. Overall, a photoperiod of $2 \mathrm{~h} / \mathrm{d}$ and light intensity of $750 \mu \mathrm{mol} \cdot \mathrm{m}^{-2} \cdot \mathrm{s}^{-1}$ increases the appearance, nutritional quality, antioxidant capacity, and yield of sweetpotato sprouts. Therefore, use of these light and photoperiod conditions should enable the production of crispy, high-quality, and high-yielding sweetpotato sprouts.

\section{Literature Cited}

Alessandrini, L., F. Balestra, S. Romani, P. Rocculi, and M.D. Rosa. 2010. Physicochemical and sensory properties of fresh potato-based pasta (Gnocchi). J. Food Sci. 75(9):542-547, doi: $10.1111 /$ j. $1750-3841.2010 .01842 . x$.

Arya, S.P., M. Mahajan, and P. Jain. 2000. Photometric methods for the determination of vitamin c. Anal. Chim. Acta 417(1):1-14, doi: 10.2116/analsci.14.889.

Eskins, K., K. Warner, and F.C. Felker. 1995. Light quality during early seedling development influences the morphology and bitter taste intensity of mature lettuce (Lactuca sativa) leaves. J. Plant Physiol. 147(6):709-713, doi: 10.1016/ S0176-1617(11)81482-3.

Fan, X., D.W. Thayer, and K.J.B. Sokorai. 2004. Changes in growth and antioxidant status of alfalfa sprouts during sprouting as affected by gamma irradiation of seeds. J. Food Protect. 67(3):561-566, doi: 10.1111/j.1745-4530.2004. tb00623.x.

Hong, D.O., S.H. Jeon, J.H. Kang, Y.S. Ryu, and Y.S. Lee. 2008. Effect of light quality on shape and greening of selling mungbean sprouts. Korean J. Crop Sci. 53(2).

Hsu, C.L., W. Chen, Y.M. Weng, and C.Y. Tseng. 2003. Chemical composition, physical properties, and antioxidant activities of yam flours as affected by different drying methods. Food Chem. 83(1):85-92, doi: 10.1016/S03088146(03)00053-0.

Ishida, H., H. Suzuno, N. Sugiyama, S. Innami, T. Tadokoro, and A. Maekawa. 2000. Nutritive evaluation on chemical components of leaves, stalks and stems of sweet sweet potatoes (Ipomoea batatas Poir). Food Chem. 68(3):359-367, doi: 10.1016/S0308-8146(99)00206-X.

Islam, M.S., M. Yoshimoto, N. Terahara, and O. Yamakawa. 2002. Anthocyanin compositions in sweet potato (Ipomoea batatas L.) leaves. Biosci. Biotechnol. Biochem. 66(11):24832486, doi: $10.1271 / \mathrm{bbb} .66 .2483$.

Lee, J., R.W. Durst, and R.E. Wrolstad. 2005. Determination of total monomeric anthocyanin pigment content of fruit juices, beverages, natural colorants, and wines by the $\mathrm{pH}$ differential method: collaborative study. J. AOAC Intl. 88(5):1269-1277, doi: 10.3200/JACH.54. 2.108-115.

Li, H. 2000. The principles and techniques of plant physiological and biochemical experiments. Higher Education Press, Beijing, China.

Li, H. 2015. Effects of different cultivation conditions and harvesting times on the quality of sweet potato sprouts in hydroponic culture. Zhejiang Agriculture and Forestry University, Hangzhou, China, doi: 10.7666/d.Y2977747.

Li, Q. and C. Kubota. 2009. Effects of supplemental light quality on growth and phytochemicals of baby leaf lettuce. Environ. Exp. Bot. 67(1):59-64, doi: 10.1016/j.envexpbot.2009.06.011.

Lv, Z., K. Yu, S. Jin, K. Weiyu, F. Cong, C. Peng, and L. Guoquan. 2018. Starch granules size distribution of sweet potato and their relationship with quality of dried and fried products. Starch, doi: 1800175.10.1002/star.201800175.

Lu, Y., X. Zhang, D. Deng, and J. Cui. 2014. Effects of light quality on total phenolic contents and antioxidant activity in radish sprouts. Acta Hort. Sinica 41(3):545-552.

Mølmann, J.A.B., A.L.H. Steindal, and G.B. Bengtsson. 2015. Effects of temperature and photoperiod on sensory quality and contents of glucosinolates, flavonols and vitamin $\mathrm{C}$ in 
broccoli florets. Food Chem. 172:47-55, doi: 10.1016/j.foodchem.2014.09.015.

Pérez-Balibrea, S., D.A. Moreno, and C. GarciaViguera. 2008. Influence of light on health, romoting phytochemicals of broccoli sprouts. J. Agr. Food Chem. 88(5):904-910, doi: 10.1002/ jsfa.3169.

Shi, B., L. Zhuo, and J. Yang. 2007. Effects of light on leaf color of redleaf cherry plum. J. Northeast Forestry Univ. 4:16-18.

Son, K.H. and M.M. Oh. 2013. Leaf shape, growth, and antioxidant phenolic compounds of two lettuce cultivars grown under various combi- nations of blue and red light-emitting diodes HortScience 48(8):988-995, doi: 10.1007/ s13580-013-0059-1.

Świeca, M., U. Gawlik-Dziki, and D. Kowalczyk. 2012. Impact of germination time and type of illumination on the antioxidant compounds and antioxidant capacity of Lens culinaris sprouts. Scientia Hort. 140:87-95, doi: 10.1016/j.scienta. 2012.04.005.

Tang, Y., Y. Dai, and G. Gao. 2010. Present situation and development trend of sweet potato industry in China. China Food Nutr. 8:23-26, doi: 10.3969/j.issn.1006-9577.2010.08.006.
Thwe, A.A., Y.B. Kim, X. Li, J.M. Seo, and S.U. Park. 2014. Effects of light-emitting diodes on expression of phenylpropanoid biosynthetic genes and accumulation of phenylpropanoids in Fagopyrum tataricum sprouts. J. Agr Food Chem. 62(21):4839-4845, doi: 10.1021/ jf501335q.

Villareal, R.L., S.K. Lin, and G.L.S. Chan. 1979. Use of sweet potato (Ipomoea batatas) leaf tips as vegetables II. evaluation of yield and nutritive quality. Exp. Agr. 15(2):117-122, doi: $10.1017 / \mathrm{S} 0014479700000491$. 